\title{
Childhood Anaplastic Astrocytoma
}

National Cancer Institute

\section{Source}

National Cancer Institute. Childhood Anaplastic Astrocytoma. NCI Thesaurus. Code C6215.

An anaplastic astrocytoma that arises from the central nervous system and occurs during childhood. 